See discussions, stats, and author profiles for this publication at: https://www.researchgate.net/publication/230045685

\title{
How traditional are the American, French and German traditions of public administration? A research agenda
}

Article in Public Administration · July 2011

DOl: 10.1111/j.1467-9299.2011.01949.x

\section{CITATIONS}

12

4 authors, including:

\section{Fritz Sager}

Universität Bern

260 PUBLICATIONS 2,032 CITATIONS

SEE PROFILE

Céline Mavrot

University of Lausanne

64 PUBLICATIONS 284 CITATIONS

SEE PROFILE

Some of the authors of this publication are also working on these related projects:

Governance of active welfare states View project

Project The transatlantic transfer of administrative ideas View project
570

Christian Rosser

Swiss Institute for Translational and Entrepreneurial Medicine (sitem-insel AG) 20 PUBLICATIONS 149 CITATIONS

SEE PROFILE 


\section{Pre-Layout/Pre-Print Version}

SAGER, Fritz, Christian ROSSER, Pascal Y. HURNI, and Céline MAVROT (2012). "How Traditional Are the American, the French, and the German Traditions of Public Administration? A Research Agenda", Public Administration 90(1): 129-143.

\section{How traditional Are the American, the French, and the German Traditions of Public Administration? A Research Agenda}

\section{Fritz Sager, Christian Rosser, Pascal Y. Hurni, and Céline Mavrot}

Consistent with the notion of tradition, public administration scholars usually interpret and compare administrative developments in the US, France, and Germany as inheritance, assuming continuity. However, administrative traditions have thus far not been an object of systematic research. The present research agenda aims to address this research gap by introducing the transfer-of-ideas approach as a means to examine the empirical substance of national traditions. We claim that for current research, the benefits of this approach are twofold. First, the transfer-of-ideas approach contributes to comparative public administration since it reveals in how far intellectual traditions are hybrid instead of distinctively American, French or German developments. Second, the approach may help to address the polysemous meanings of and terminological difficulties within administrative concepts that prevail in Public Administration on both sides of the Atlantic.

\section{INTRODUCTION}

Whereas the lion's share of comparative research on American and Continental European public administration has focused on the administrative practice (public administration, with lower case ' $p$ ' and ' $a$ ') (see, for example, Heady 2003), some studies have also compared public administration on both continents as it evolved in theory (Public Administration, upper case ' $P$ ' and ' $A$ ') (see, for example, Kickert and Stillman 1999; Rutgers 2001; Bevir et al. 2003). These studies usually approach the comparative history of ideas of Public Administration against the background of intellectual traditions, regarding traditions as ideal typical constructs, path dependencies, or cultural variations on a macro level (Painter and Peters 2010, pp. 4-5). While intellectual traditions are highly useful as conceptual maps, it is debatable to what degree such schematic models are empirically valid. It is the intention of this paper to introduce the transfer-of-ideas approach - an approach that is able to deal analytically with the empirical substance of intellectual traditions as self-referential path dependencies within comparative Public Administration.

In their book on Tradition and Public Administration, Painter and Peters (2010, p. 19; see also Kickert and Stillman 1999, p. 6) identify four sub-traditions or, to put it in their own words, four 'discrete families comprising groups of countries within the Western cultural tradition', each sharing a similar intellectual inheritance: the Anglo-American, the Napoleonic, the Germanic, and the Scandinavian. With regard to the first three intellectual traditions, in the sense of a most different case scenario, the research agenda concentrates on the US, France and Germany. According to Painter and Peters (2010, p. 20), the manifestation of the Anglo-American tradition 'is taken to its greatest extreme in the United

Fritz Sager is in the Center of Competence for Public Management and Christian Rosser and Pascal Hurni are PhD Candidates in the Center of Competence for Public Management, University of Bern. Céline Mavrot is in the Swiss Graduate School of Public Administration (IDHEAP), Lausanne and a PhD Candidate in the Center of Competence for Public Management, University of Bern. 
States'. With regard to the Napoleonic and the Germanic tradition, the same can arguably be said about France and Germany respectively (Painter and Peters 2010, pp. 21-2). Owing to lack of proficiency in the relevant languages, we unfortunately have to exclude the Scandinavian tradition from the discussion. Hence, to present empirical evidence in support of or against the notion of distinct intellectual traditions, we intend to examine the transfer of ideas among American, French, and German Public Administration scholars of the 20th century. As we aim to capture the empirical substance of intellectual traditions as self-referential path dependencies, the transfer-of-ideas approach focuses on paradigms as units of investigation rather than on techniques that are applied specifically in administrative practice.

The paper has five sections. First, we discuss how the concept of intellectual traditions has been used in comparative Public Administration. Second, we recapitulate the state of the art on the transfer of administrative ideas among American, French, and German scholars of the 20th century. The discussion of existing research will show that even though there has been considerable intellectual interaction, the transfer of administrative ideas has not been analysed in a comprehensive and systematic manner. The two subsequent sections discuss the analytical framework of the transfer-ofideas approach with which this research gap may be filled. As regards theory, we propose a model that is capable of accounting for the empirical substance of intellectual traditions. As regards method, we outline a content analysis that enables us to select, structure, and examine the body of sources. In the concluding section we discuss in how far contemporary Public Administration scholarship may profit from a comprehensive analysis of the transatlantic transfer of administrative ideas.

\section{THE ADMINISTRATIVE TRADITIONS OF THE US, FRANCE AND GERMANY}

If the history of US administrative thought is conceived of as a path dependent, incremental development, the American tradition of thinking about public administration can be interpreted as a statelessness narration. This stands in contrast to the Continental European narration, where the state has always been the centre of gravity (Stillman 1997; Kickert and Stillman 1999; Rutgers 2001; Stillman 2001). In what follows, we recapitulate how this notion of tradition has been used in the literature, first by looking at the example of the US, and then at the cases of Germany and France.

Stillman (2003, p. 19) states that 'at the heart of the American political tradition, antistatism endures as the core belief that is evidenced over and over again during the past four centuries of American political life'. In the liberal tradition of social compact theories following the likes of Montesquieu and Locke (Lutz 1984), government has been conceptualized around fundamental and inalienable rights such as equality, property, and individual liberty. The protection of these constitutional principles continues to be understood as the main reason for political organization in the US. According to Spicer (2004, p. 356), this form of organization may be labelled as a civil association 'in which men and women see themselves as free to pursue their own particular interests and values. What binds them together as a political group is not any common set of substantive ends or objectives, but their common recognition or acknowledgement of certain rules of conduct'. Hence, the government is interpreted 'more like an umpire than a manager' and public administration is clearly not conceived as the guardian of the public interest (Spicer 2004, p. 357). Kickert (2001, p. 28) maintains that 'bureaucrat bashing is a most popular sport in the States'.

Not only has the mainstream of US intellectuals disapproved of a powerful federal state, but also of an influential public administration. On the federal level, administration is primarily linked to the 
executive and the lion's share of public responsibility is assigned to elected representatives (Rutgers 2001, pp. 230-1). Other than that, local self-government and a well attuned (inter)active relationship between citizens and the political institutions are considered to correspond with the societal needs. In his article on the usefulness of administrative traditions, Raadschelders (2007, pp. 3-4) illustrates how the American way of dealing with social conflicts is sometimes called "the "village model" where conflict is resolved by considering the specific situation at hand'.

With regard to the training of Public Administration scholars, US universities have focused on the education of social scientists and managers rather than lawyers. Administrative knowledge has generally been acquired on the basis of methodological individualism. US scholars give priority to individuals or interest groups and stress governance - instead of government - as the core concept of their endeavour. As practitioners rather than theoreticians, intellectuals tend to induce administrative subject-matters from the relevant praxis. It is the empirical context that constitutes administrative principles and not vice versa as in Continental Europe (Stillman 1997). In addition, American scholars often lay their focus on prescriptive studies because it is administrative science which tells the critically perceived state what to do and, maybe more importantly, what not to do. Finally, Public Administration in the US has traditionally favoured a non-historical approach (see, for example, Stillman 1997, p. 335; Spicer 2004, p. 359).

According to Painter and Peters (2010, p. 6), 'the alternative to the contractarian notion of the state is a more organic view, in which state and society are intertwined to the extent that it is almost impossible to separate them. [...] Continental political systems such as Germany and France have the clearest organic conception of the state'. We may thus label both the French and the German form of political organization - again in Spicer's (2004, p. 355) terminology - as purposive association 'in which individuals recognize themselves as united or bound together for the joint pursuit of some coherent set of substantive purposes or ends'. French and German citizens habitually expect the state to play an active role in the resolution of social conflicts. Stillman (1997, p. 334; see also Raadschelders and Rutgers 1999) notes that in Continental Europe, the state 'was the centrepiece around which most conflicts were fought, from the Renaissance and Reformation through the twentieth century. The concept of the state also defined the political thought of those centuries'.

Chevallier (1996, p. 67) holds that the 'French strong state tradition decisively shapes both its past and present development of public administration'. In the early 19th century, practice-oriented work of French authors was linked with the development of the monarchic state and the centralization of administration. Later, the emergence of the liberal state induced the monopoly of the juridical approach. The question of the legal framing of state activity obtained priority, and the knowledge on public administration increasingly became the prerogative of the law faculties and the Conseil d'Etat. This anchorage of administrative law in the rule of law involved a focalization on the specificities of public administration. After the Second World War, however, several reform movements gave birth to a renewal of administrative sciences. Thus, since the 1960s, French administrative science has fluctuated between three models, emphasizing either legal, managerial or sociological dimensions. These models generally identify the state as the administration's centre of gravity (Chevallier 1996).

In the second half of the 19th century, the scholarly treatment of public administration in Germany also became dominated by jurisprudence. According to Seibel (1996, p. 75), the 'relatively rigid legal structure that was the backbone of public administration turned out to be a desirable counterweight to the volatility of the political structure in 20th century Germany'. While the dominance of lawyers in 
academia and in public administration prevailed, Scharpf (1970) criticized the Rechtsstaat as too rigid and inflexible to respond to the emerging societal and political changes, and thus challenged the organizational structure of bureaucracy. Not until the 1970s was it possible for Public Administration to develop as an academic field, first within political science and then as an increasingly distinct discipline. Even though the perception of the state has shifted 'from democratic via active and lean to the activating state, [...] Germany is to a large extent still a heavily state-based society, and the dispute about the proper role and understanding of the state lies at the heart of much of the current debate' (Jann 2003, p. 96).

Despite the dissimilarities in their respective developments, France and Germany share common grounds in the conception of the state. For example, besides being an institution, the state is considered to be the normative frame encompassing the various estates and the trustee of the general interest. Additionally, scholars from both countries attribute a distinct legitimacy to the state itself, for it is perceived as standing above any particular group of society (Benz 2001, p. 39). The basic idea among intellectuals is that the state has always existed a priori and that the bureaucratic apparatus has grown in close correspondence with the state. This may be a reason why French and German scholars have often put emphasis on the historical evolution and modernization of the bureaucratic apparatus. The state is usually interpreted as apolitical, noneconomic, and non-utilitarian in character as well as dependent on the sovereignty of the people. Both the French and German public administrations, which are conventionally referred to as the working state, are identified as largely independent of politics. This explains the relevance of public administration for the development of the state and the implementation of the public good. Public servants have therefore often been regarded as 'legitimate guardians of the public interest' (Rutgers 2001, p. 228).

The high importance of jurisprudence within French and German Public Administration may explain why the concrete administrative praxis has generally been deduced from theoretical principles. Overall, the features of Public Administrations in Germany and France have led to a scientific discipline which derives administrative principles from state principles in general and law principles in particular (Seibel 1996, p. 75; Stillman 1997, p. 335; Jann 2003, pp. 98-9; Rutgers 2003, pp. 244-50). As a consequence, the European focus is primarily on analytical studies, on bureaucratic theory as well as on the description of facts.

If we approach the history of administrative ideas with the notion of intellectual traditions, we risk implying that in Continental Europe and in the United States public administration research has always followed distinct incremental paths. With regard to the unifying effect of globalization and the influence of New Public Management (NPM) in Western academe (Lynn 2006), most scholars would certainly reject this generalization. Moreover, Painter and Peters $(2010$, p. 139) hold that hybridity in administrative traditions appears to be the rule rather than the exception. However, as Raadschelders (2007) claims, public administration scholars continue to interpret and compare administrative developments as inheritance, assuming continuity. Thus far, the intellectual traditions of US, French and German Public Administration have not been 'an object of systematic, empirical research' (Raadschelders 2007, p. 6). We aim to introduce an approach that addresses this research gap by analysing the scholarly exchange among the US, the French and the German tradition. In the discussion that follows, it is therefore essential to recapitulate the state of research on transnational fertilizations among scholars from the three countries. 


\section{THE STATE OF THE ART ON THE TRANSFER OF ADMINISTRATIVE IDEAS}

First, with regard to the transfer of ideas from Germany to the US, it should be noted that during the late 19th century, animated intellectual interaction took place between German universities and the nascent American universities. It is hardly an exaggeration to say that during this period, the whole US political science - of which Public Administration cannot be separated at this time - was under great influence from German political theory. In order to deal with their contemporary administrative problems, Ely, Wilson, and Goodnow consulted Hegel's political philosophy as well German textbooks on public administration and public law (Heady 1995, p. 64; Sager and Rosser 2009; Overeem 2010, pp. 55-70; Rosser 2010).

Another significant perception of German administrative thought among American theoreticians took place after World War II when attention was drawn to Weber's study of bureaucracy (Raadschelders 1998, pp. 112-35; Beetham 2006; Scaff 2006). Considering Weber's eminent position in administrative research, this represents a most interesting case of transfer. According to Scaff (2006, p. 56), a requirement for the appreciation of Weber's work among US scholars was'a certain resonance or convergence of Weber's basic assumptions and questions with American conditions and with issues having some prominence in American social and intellectual life'. For example, US students of Public Administration have often stressed the remarkable similarities between Wilson and Weber's classical conception of Public Administration (Sager and Rosser 2009). Presumably, rather imprecise translations have helped to foster convergence. Schreurs (2000, p. 70) reminds us that, for instance, Weber's term Leistung was translated as efficiency, even though performance would have been more fitting. It goes without saying that efficiency has been a prominent issue in American scholarship ever since the scientific management movement.

In addition, the subject of what ideas Morstein Marx brought from Germany to the US has not yet been considered in detail. He wrote extensively on both Continental European and US public administration. Morstein Marx was among the many German trained jurists who, before their immigration to the US in the 1930s, had already held office in German law schools. Like compatriots such as Fried, Löwenstein, Morgenthau, Niemeyer and Simons, Morstein Marx later became a well known scholar in America (Stiefel and Mecklenburg 1991, pp. 78-80). In the 1960s, for example, he wrote two articles in the Public Administration Review which informed an American readership of the state of the art and the future needs of German Public Administration (Marx 1967, 1969). There, he also quoted French authors such as Thuillier, Lenoel, Macarel, and Vivien.

The writings of Mayntz and Scharpf provide examples of how more recent German research may have influenced Public Administration in America. As far as we know, no analyses of the transfer of their ideas have been undertaken thus far. Not only the reception of the administrative thought of Mayntz and Scharpf, not only in the US, but also in Germany and France, is interesting. Both scholars worked at US universities and, depending on the context of their writings, they may be interpreted as intellectuals who stand in line with the American intellectual tradition. Their academic work may therefore illustrate how fertilization can actually become cross-fertilization.

As regards the French background of the nascent American Public Administration, it should be mentioned that nearly every early student in the field dealt by some means or other with the political institutionalism of Montesquieu (Rutgers 2000). Furthermore, Martin (1987, p. 297) holds that '[v]irtually every significant concept that existed in the American literature as late as 1937 had already 
been published in France' by the first half of the 19th century. Authors such as Macarel, Vivien, Dupin and Laboulaye dealt with Public Administration as an autonomous field of study, the politicsadministration dichotomy and/or deducible scientific and thus stable principles (for example, POSDCORB) for public administration long before their US colleagues. Whether or not these American and French authors drew similar conclusions independently, for example as a response to a common problem, or whether or not they did so due to the transfer of ideas, has not yet been analysed.

As the following three examples may show, Tocqueville's influence on US Public Administration seems to be equally important to that of Montesquieu. Two years after the first publication of the Public Administration Review, Smith drew attention to Tocqueville's 'significance as a thinker on public administration' (Smith 1942, p. 221). According to Smith (1942, p. 229), Tocqueville had excellent knowledge about Continental European administrative practices and, as a consequence, 'was able to apply to the American system standards of evaluation and techniques of analysis virtually unknown on this side of the Atlantic. He was perhaps the first investigator to appraise administrative practices in the United States in terms of such concepts as hierarchy, discipline, coordination, personnel practice, degree of professionalization, and the like'. Interestingly, Tocqueville was one of the first political thinkers to report on the stateless administration in the US (Cook 1996, p. 18). Furthermore, Vincent Ostrom (1997) has dedicated an entire book to Tocqueville's expertise with the aim of asserting the strength of relationships among individuals and their self-organizing behaviour as critical factors for the establishment and survival of a democratic political system.

Fayol's Industrial and General Management, which was published in French in 1916 but not translated into English until 1930, was an important source of inspiration for Gulick and Urwick's Papers on the Science of Administration which first appeared in 1937 (see Henry 1987, pp. 43-4). A couple of years later, American scholars seem to have forgotten about the French antecedents of their Public Administration (Martin 1987, p. 301). During the conservative 1980s, Fayol's writings became important enough to again be published in the United States. As Wolff (1984, p. xi) declared, argumentations that were considered 'wrong or totally inappropriate to modern management concepts' had been omitted. Furthermore, the terms efficiency and inefficiency were added to some translations of Fayol's work. Schreurs $(2000$, p. 73 ) reveals that 'the terms "bon" and "mal" have been translated as "good" and "bad", but have been translated even more often as "efficient" and "inefficient". Although "bon" and "mal" do not necessarily exclude efficient and inefficient, these terms also have a moral connotation. This moral point of view is lost when "bon" is translated as "efficient"'.

Existentialist philosophy probably also exerted a certain influence on US Public Administration, especially during the 1960s and 1970s. Some American scholars such as McCurdy, Richter and Wilcox seem to have been inspired by what Camus, Marcel and Sartre thought about public authorities (Waugh 2006). In the Handbook of Organization Theory and Management, Waugh (2006) elaborates on the existentialist public administrator. Finally, attention should be drawn to the writings of Rohr (1993, p. 473; see also 1995) who comes to the conclusion that 'France has long been a fruitful object of comparative studies for American students of public administration. The reason is clear enough: France is sufficiently similar to the United States to make comparisons meaningful and different enough to make them interesting'.

As regards the appreciation of American administrative research in Germany, the perception of Weber's administrative writings serves as another good example to show how fertilization can become 
cross-fertilization. In the 1960s, many German intellectuals interpreted and criticized Weber's writings, which emphasized the role of a strong bureaucracy, as an anachronistic legitimization of the Nazi regime. It was largely due to American social scientists such as Parsons that by the end of the 1960s the German response to Weber shifted back to a more favourable reception of his concept of power. As Anter (2000, p. 131) points out, 'within a few decades, Weber's ideas were reinterpreted due to their transfer from Germany to the US and back'.

As a general statement, we can say that ever since the end of World War II, American Public Administration has strongly influenced administrative study in Western Europe. According to Kickert and Stillman (1999, p. 4), 'the postwar developments of administrative sciences in various Western European countries show an almost exclusive orientation toward the United States'. With regard to public management related reforms, we can assume that the influence of US Public Administration on both French and German scholarship has been especially significant since the 1960s. Kickert (2001, p. 28) claims that the reliance of European 'scholars on the Northern American study of Public Administration is striking. This is not surprising because at the time when the European policy and administrative sciences were resurrecting in the post-war welfare states of the 1960s and 1970s, this field was more than half a century old in the United States. The sheer quantity of the accumulated body of knowledge in the United States and the eminent quality of its many renowned PA scholars implied that the American field became the "wise big brother" to admire'.

In post-war Germany, more than 1000 publications on scientific management appeared (Nelson 1992, p. 23). In this context, Gulick and Urwick's Papers on the Science of Administration played an important role in German Public Administration. In the 1990s, when American NPM concepts enjoyed popularity among German scholars, classic scientific management principles were reconsidered as well. For example, Kickert (2001, p. 31) states that the 'conceptual frame of reference of a public management derived in Budäus (1994) consists of concepts such as planning, organization, leadership, personnel, and control - highly similar to POSDCORB - and is closely related to the early 20th century American approach to management'.

In France, the scientific management movement was also important. Ironically, Taylor's work was widely noted in France whereas, after a brief period of appreciation, Fayol's writings were largely forgotten. This changed after World War II, when Fayol's administrative ideas were re-introduced by American consultants during the industrial reconstruction and the implementation of the Marshall plan (Braun 1967, Morin 1979, p. xii). Similarly to the Weberian example mentioned above, Americans thus helped European scholars to appreciate their own administrative writings.

With regard to the reception of Public Management concepts in 1960s France, Kickert (2001, p. 30) points to the fact that 'under the influence of the American (business administration) management and organization sciences, concepts such as gestion publique and management publique were introduced to government as an approach differing from the juridical'. Further case studies on the subject have been provided by Romano (2003) and Gemelli (1997). However, thus far, there has been no comprehensive analysis of the transfer mechanisms of the import of scientific management concepts and business-based studies from the USA to France and Germany.

Crozier was one scholar who was heavily influenced by his American colleagues. He played a decisive role by creating the sociological school of organizations in France, spreading the idea that public and private organizations can be analysed with the same tools. His theoretical frame was largely inspired 
by American social psychology, March and Simon's Organizations (1958), and later March's (1994) theories of strategic decision. According to Crozier $(2002,2004)$, the dialogue with his American peers was crucial to escape a French academic field dominated by unempirical structuralism.

In a preliminary conclusion, it seems safe to state that there has been considerable intellectual exchange among US, French, and German Public Administration scholars. However, comparative studies usually conceptualize administrative traditions as largely isolated and autonomous developments. To our knowledge, the empirical substance of administrative traditions has not been analysed in a systematic manner. The two sections that follow are dedicated to the discussion of an analytical framework which aims to fill this gap with a comprehensive examination of the transfer of administrative ideas. We first introduce a theoretical model with which to conceptualize the process of transfer before we turn to a more concrete discussion of how to operationalize this transfer.

\section{THEORIZING THE TRANSFER OF IDEAS}

We intend to analyse to what extent two underlying (and largely unquestioned) assumptions of comparative Public Administration are valid. On the one hand, we aim to test how far intellectual traditions of Public Administration have developed independently and, on the other hand, we attempt to examine the homogeneity shared within and between the different traditions. We define an intellectual tradition of Public Administration as 'a set of inherited beliefs about the institutions and history of government' that 'someone receives during socialization' (Bevir et al. 2003, p. 6). To provide an unambiguous definition of the transfer of ideas, it may be useful to briefly recapitulate the literature on culture transfer - a research strand developed in Germany and France comparatively recently (see, for example, Kaelble 2003; Suppanz 2006). This body of literature constitutes a sub-field of relational history which, in general, deals with interrelations between culturally distinguishable historical subjects and the emergence of new phenomena as the result of such interrelations (Osterhammel 2003, p. 444). Within the discipline of relational history, the most important concepts used to address these interrelations were labelled diffusion, interdependence, intertextuality, and transfer (Kaelble 2003).

The first distinguishing characteristic between transfer and the other concepts may be found in the focus on either the sending or the recipient culture. While, for example, diffusion analyses may concentrate on the sending culture or put equal importance on both sides, the transfer literature generally focuses on recipient authors and their context. Hence, transfer studies attach more weight to understanding the import than the export of foreign ideas. The second distinguishing characteristic between transfer and the other concepts is intentionality. Whereas transfer is regarded as an intentional and purposeful process, the other concepts are often concerned with unintended, adaptive interrelations (see Osterhammel 2003, p. 448). Scholars dealing with culture transfer usually assume that the incentive of actors to acquire knowledge about another culture is the desire for changing their own intellectual inheritance (Lingelbach 2002, p. 355). In this respect, the logic of interpretation of the transfer-of-ideas approach ties in with Bevir's (2002) approach to the history of ideas. Our assumption is that we 'can explain why people changed their beliefs in the way they did by presenting the new webs of belief as responses to dilemmas that confronted the old ones' (Bevir 2002, p. 200). Bevir (2002, p. 198) suggests that a 'dilemma should be understood here as any new understanding, whether based on an interpreted experience or reflection upon their existing beliefs, that stands apart from one's existing beliefs and so forces a reconsideration of them'. Scholars may adopt new webs of belief when they promise to solve contradictions contained in the old one. 
Accordingly, the transfer of ideas is defined as a recipient group of scholars' intentional importation of foreign administrative knowledge. More specifically, the dynamic of the transfer of ideas can be differentiated in three analytical steps: (1) mediation; (2) selection; and (3) reception (Lüsebrink 2001, pp. 215-17). Mediation has to do with the actors who transfer ideas and with the institutions that allow for the transfer (who). Selection processes deal with the texts and scholarly discourses that are chosen to be transferred from one context to the other (what). With regard to method, mediation and selection call for an inductive and descriptive research strategy that aims at finding out the 'who' and 'what' aspects of transfer. In the section that follows we will discuss how we intend to identify a body of sources that is adequately representative. Finally, reception processes surround all aspects of how transferred texts are embedded in the context of the recipient intellectual tradition - something we will also touch on.

As regards reception processes, we formulate a model according to which three patterns of reception can be distinguished. The two most extreme conceivable patterns may be labelled rejection and adoption; the intermediary pattern may be called modification. On the one hand, rejection occurs when recipient academicians refer to a foreign author in order to formulate an administrative concept in explicit opposition to this foreign expertise. On the other hand, we speak of adoption when recipient scholars quite literally copy an administrative concept according to its original meaning. Alternatively, modification represents the adequate pattern of reception when a recipient academician adapts a concept according to the domestic experience and consequently changes the concept's original meaning more or less substantively during the transfer.

Since we are dealing with texts written in English, German or French, special attention needs to be paid to the issue of translation. Ideally, a translation is the process of establishing equivalence between the meaning of an utterance in the recipient's and an utterance in the sender's writing. However, as the examples given in the section above indicate, it has to be expected that, in reality, translations usually represent reinterpretations (that is, modifications). It cannot be simply assumed that the meaning of an utterance is language independent. Arguably, the meaning of an utterance is determined by its semantic context (Rutgers 1996). To trace a modification caused by translation, it is therefore indispensable to interpret the recipient's utterance as a contribution to the contemporary discourse in the ideational context of the recipient.

It may be useful to illustrate the respective patterns of reception with three examples. The rejection pattern may be exemplified against the background of the reception of Weber's ideal type of bureaucracy among American organizational sociologists in the 1950s and 1960s. In explicit opposition to the Weberian ideal type, scholars such as Presthus and Thompson formulated innovative administrative concepts dealing with bureaucratic dysfunction such as the inefficiency of strict rule application, red tape, and resistance to change (Raadschelders 1998, pp. 112-13). Despite their rejection of Weber's expertise, American scholars 'were in a better position to understand why bureaucracies went awry' once they had read Weber (McCurdy 1986, p. 37).

To exemplify the adoption pattern, we may refer to Wilson's reception of German ideas about the proper relationship between politics and administration. Very much in the sense of what he had read in Bluntschli's and Stein's textbooks, Wilson contrasted legislation and administration in order to distinguish between general plans and special means of governmental activities. Wilson saw in public administration the means to compensate for the gradual pace of legislation. He thought that a body of altruistic, devoted public servants would promote the common good of society, which he believed had 
primacy over the good of the individual. The administrative concepts Wilson came to appreciate while reading Bluntschli and Stein apparently inspired him to respond to pressing societal problems. He believed that a powerful administration would save people from the destructive influence of corruption and the egoistic individualism of laissez-faire liberalism. In order to protect public administration from these dilemmas, Wilson formulated a politics-administration dichotomy that was very much in the German tradition of thinking about the state and its functions. Hence, our research on Wilson's reception of German administrative theory (Sager and Rosser 2009; Rosser 2010) substantiates the findings of Miewald (1984, p. 18) who concludes that Wilson 'never achieved a thoroughly American administrative theory'.

To illustrate the modification pattern, we may draw attention to the French and German administrative reforms of the 1980s and 1990s. Scholars from both countries imported characteristics of American NPM such as business management techniques (for example, steering versus rowing), service and client orientation, privatization, and market-type mechanisms (Kickert 2001, p. 18). However, the French and the German intellectual traditions seem to have set limits on the implementation of NPM reforms. Pollitt and Bouckaert (2004, pp. 52-3) maintain that traditional philosophies and cultures of governance are crucial when it comes to explaining why Anglo-Saxon countries implement NPM strategies more easily than Rechtsstaat systems such as Germany and France. Because of the strong state tradition, Public Administration in France and Germany is less inclined to import ideas from the private sector such as market incentives and competition. The prominence of juridical approaches within Public Administration has additionally complicated the adoption of managerial thinking (Jann 2001; Rouban 2001). We may thus conclude that while the ideas about public management reforms are highly similar throughout the Western world, the interpretations of these ideas differ (Peters 2001, p. 262).

On the whole, the longitudinal analysis and codification of reception processes will permit us to empirically strengthen or deconstruct the notion of intellectual traditions as incremental path dependencies. If in a specific transfer situation, rejection or a significant modification of foreign knowledge represents the adequate pattern of reception, the finding corroborates the notion of an intellectual tradition as a self-referential path dependency. If, in the reverse conclusion, a transferred concept is only slightly modified or received according to the adoption pattern, the notion of continued intellectual tradition is put into perspective, that is, relativized.

\section{MEASURING THE TRANSFER OF IDEAS}

We consider a content analysis of eminent writings of American, German and French authors of Public Administration to be the appropriate means to analyse the transfer of ideas. Bowen and Bowen (2008, p. 689) understand a content analysis as 'an explicit sequence of steps with which to systematically organize elements of text so as to enable an investigator to meaningfully interpret and make inferences about the patterns in the content of the overall body'. We suggest that in order to comprehensively examine the transfer of ideas, this sequence of steps ought to consist of: (1) identifying the appropriate body of sources; (2) formulating a framework to classify the body of sources; (3) applying the classification framework to the individual units of the body of sources; and (4) drawing inferences from the patterns identified in the overall body. 


\section{Identifying an appropriate body of sources}

Due to the length of the period under consideration, the quantity of sources for the study of the transfer of administrative ideas among US, French and German scholars is potentially overwhelming. A sensible strategy is therefore needed to identify a body of sources that represents the whole. With regard to American authors, McCurdy's (1986) bibliographic guide to the administrative literature provides access to a representative sample of seminal writings. All the books in his bibliography 'were identified by cross referencing a series of reading lists, textbook citations, and specialized bibliographies prepared by experts in the field' (McCurdy 1986, p. iv). Sherwood (1990) offers a similar overview of the most influential American publications. He asked 25 colleagues to 'recommend the five or six books that have had the most influence on public administration' (Sherwood 1990, p. 250). As regards Germany and France, two proceedings catalogue the most influential publications of German and French administrative scholars. First, assuming that the most important subjects, authors, and Leitbilder are included in textbooks, it will be possible to infer from 20th century textbooks what texts the body of sources should consist of. Second, an expert survey analogue to Sherwood's endeavour will provide us with an alternative sample. As the two approaches yield a different bias, a combination of both types of proceedings promises the best result.

\section{Formulating a framework to classify the body of sources}

To stipulate a framework to classify the body of sources, we draw on the literature dealing with multiple paradigms of Public Administration and interpret the developments of the field of study in the US, France and Germany against the background of paradigms or dominant discourses (see, for example, Henry 1987; Chevallier 1996; Jann 2003; Holzer et al. 2007; Yang et al. 2008). It goes without saying that any description depicting the development of Public Administration as a mere succession of chronologically and thematically exclusive paradigms is misleading. Such a simplistic understanding does not do justice to the diversity and colour of the field of study. However, as Yang et al. (2008, p. 25) claim, it is equally problematic to let 'a hundred flowers bloom without knowing the family lineage of the flowers'. Even if paradigms may be permeable and sometimes mutually overlapping, for the sake of analytical clarity, we conceive of them as fundamentally different.

A paradigm has to do with the inter-subjective production of meaning among a group of administrative scholars. Paradigms usually refer to the fundamental question of what Public Administration ought to be or what it actually is. They constitute a coherent, shared view about 'an intellectual framework that specifies the discipline's proper domain, basic assumptions, appropriate research questions, and rules of inference' (Yang et al. 2008, p. 25). As a group of researchers sharing such a coherent view may be interpreted as a discourse community, we operationalize the written manifestation of paradigms with the concept of discourse. According to Rutgers (2003, p. 12), the 'process of conceptualization by a multiplicity of authors and actors can be called a discourse. [...] discourse provides us with a term to capture conceptualization over time. Discourse concerns the continued, enduring and interactive exchange, creation, and debate of shared interpretations (meanings)'. Public Administration in the US, France and Germany may be considered to consist of several dominant discourses and analysed as such. Consistent with what has been stated above, it is argued that each new paradigm emerged (partially) as a reaction to the intellectual dilemmas inherent in another paradigm. 


\section{Applying the classification framework to the individual units of the body of sources}

Consistent with the multiple paradigm approach, sources are regarded as artefacts of a discourse which represents a cluster of writings as a whole, rather than a sum of individual statements. In order to provide sensible interpretations and, to some extent, insightful generalizations, the authors of both sides of the Atlantic and their respective writings ought to be interpreted as belonging to a paradigm. Once we have classified the relevant sources, our aim is to conduct a citation count as a surrogate measure of the relative impact of German and French authors on US administrative thought and vice versa (Lutz 1984). Not until the senders' writings have been identified in the recipients' texts, will we be able to approach their reception analytically. Assuming that we can understand the meaning of a text, we can compare the meaning of an idea in the original publication with the meaning of the idea as it is applied by the recipient author. In other words, qualitative comparative text analysis will provide access to the 'how' aspects of transfer.

\section{Drawing inferences from the patterns identified in the overall body}

The purpose of the content analysis of eminent American, French and German administrative writings is to characterize the transfer of administrative ideas among the respective authors. We aim to recognize patterns of reception of foreign knowledge among those authors and, subsequently, we intend to make inferences from these patterns. In order to test for the empirical validity of administrative traditions, we apply our model one, as discussed above, that distinguishes between the three patterns of reception: rejection, modification and adoption. Depending on whether, in a specific transfer situation, the reception lies closer to the pattern of rejection or adoption, the notion of intellectual traditions can either be substantiated or put into perspective. On an aggregate level, the content analysis should enable us to draw insightful conclusions about how administrative scholarship in the US, France and Germany has been influenced by knowledge from the other side of the Atlantic.

\section{THE NEED FOR A CLOSER LOOK AT TRADITIONS OF PUBLIC ADMINISTRATION}

In this paper, we have illustrated that the statelessness tradition of the US and the stateness tradition of France and Germany represent typical conceptual maps to compare the three countries' administrative developments. Subsequently, we have outlined the transfer-of-ideas approach and have introduced the patterns of rejection, modification and adoption to grasp the empirical substance of the notion of tradition. In this section, we discuss in what respect contemporary research may profit from a comprehensive examination of the reciprocal fertilizations among American, French and German intellectuals.

First, the analysis of the transfer of administrative ideas in general and the distinction between rejection, modification and adoption in particular will help to address the polysemous meanings of and terminological difficulties within administrative concepts. Hitherto, scholars from both sides of the Atlantic have generally used the same vocabulary. This has caused both misunderstanding and misinterpretation. Rutgers (2001, pp. 238-9) holds that, the 'main lesson to be learned is that one has to be careful in borrowing ideas from the other tradition. [...] Similarities are claimed too quickly; closer examination can reveal interesting differences in meaning [...] and thus provide new theoretical and practical insights'. As our research programme deals with the very borrowing of foreign ideas, it will be able to identify similarities and differences in meaning and put them into perspective. 
Arguably, it is in the nature of comparative studies that they concentrate on differences between administrative paths rather than analogies. Doing so may suggest that the three paths of Germany, France and the US have always proceeded separately and continue to do so. The transfer-of-ideas approach does not consider spatio-temporal units of analysis, such as administrative paths and their mutual boundaries, a priori, as historically adequate descriptions. We do not contend that comparative scholars may not arrive at the same conclusion. They would probably argue that the adequacy of intellectual traditions depends on how high we fly (that is, whether we engage in a micro- or macrohistorical study). However, the transfer-of-ideas approach combines different levels of generality. On a micro level, the thorough examination of primary sources enables us to adjust the conceptual maps we apply on the macro level. It is the comparison of individual transfer processes and the longitudinal classification of these processes that provide insights into the empirical substance of the chosen units of comparison - intellectual traditions of Public Administration - on both the micro and the macro level.

Moreover, in contrast to the plethora of comparative studies, the transfer-of-ideas approach does not give centre stage to parallel structural characteristics and processes of two units of comparison, but to their semantic reinterpretation(s) caused by the very transfer of ideas. Conducting deductive comparative research against the background of self-referential intellectual traditions may have the effect of partly prefiguring the results. The transfer-of-ideas approach does not refrain from relying on clear cut units of comparison as analytical categories. However, 'its inductive orientation aims to limit effects through an investigative mechanism in which the objects, categories, and analytical schemes are adjusted in the course of research' (Werner and Zimmermann 2006, p. 46). As a consequence, hybrid intellectual cultures, something that common sense may accept right from the outset, do no longer form a blind spot in comparative Public Administration. The examination of the transfer of ideas may show that it is more realistic to interpret intellectual traditions as crossbreeds, instead of distinctively and uniquely American, French or German breeds. As a contribution to the history of ideas, the research program arguably matters, for it may uncover 'facts instead of perpetuating fiction' (Raadschelders 2007, p. 18). Just as well as we may find out that intellectual traditions of Public Administration are perpetuating fiction, we may discover that they are actually perpetuating facts.

\section{REFERENCES}

Anter, A. 2000. 'Max Weber (1864-1920)', in W. Bleek and H.J. Lietzmann (eds), Klassiker der Politikwissenschaften. Von Aristoteles bis David Easton. München: Verlag C.H. Beck, pp. 123-36.

Beetham, D. 2006. 'Weber and Anglo-American Democracy: Analysis, Reception and Relevance', in K.L. Ay and K. Borchardt (eds), Das Faszinosum Max Weber. Die Geschichte seiner Geltung. Konstanz: UVK, pp. 343-51.

Benz, A. 2001. Der moderne Staat: Grundlagen der politologischen Analyse. Munich: Oldenbourg.

Bevir, M. 2002. 'The Role of Contexts in Understanding and Explanation', in H.E. Bödeker and M. Bevir (eds), Begriffsgeschichte, Diskursgeschichte, Metapherngeschichte. Göttingen: Wallstein, pp. 159208.

Bevir, M., R.A.W. Rhodes and P. Weller. 2003. 'Traditions of Governance: Interpreting the Changing Role of the Public Sector', Public Administration, 81, 1, 1-17. 
Braun, R. 1967. 'Témoignage', in Le Cinquantenaire de la Doctrine administrative. France: Imprimerie de Chartres et Conservatoire National des Arts et Métiers.

Budäus, D. 1994. Public Management. Berlin: Edition Sigma.

Chevallier, J. 1986. Science Administrative. Paris: Presses Universitaires de France.

Chevallier, J. 1996. 'Public Administration in Statist France', Public Administration Review, 56, 1, 6774.

Cook, B.J. 1996. Bureaucracy and Self-Government: Reconsidering the Role of Public Administration in American Politics. Baltimore, MD: JHU Press.

Crozier, M. 2002. Ma belle époque. Mémoires 1947-1969. Paris: Fayard.

Crozier, M. 2004. A contre-courant. Mémoires 1969-2000. Paris: Fayard.

Gemelli G. 1997. 'Les écoles de gestion en France et les fondations américaines (1930-1975). Un modèle d'appropriation créative et ses tournants historiques', Entreprises et Histoire, 14, 15, 11-28.

Heady, F. 2003. 'Comparison in the Study of Public Administration', in E.E. Otenyo and N.S. Lind (eds), Comparative Public Administration: The Essential Readings. Oxford: Elsevier, pp. 61-127.

Henry, N. 1987. 'The Emergence of Public Administration as a Field of Study', in R.C. Chandler (ed.), A Centennial History of the American Administrative State. London: Collier Macmillan, pp. 37-85.

Holzer M., V. Gabrielian and K. Yang. 2007. 'Five Great Ideas in American Public Administration', in J. Rabin, W.B. Hildreth and G.J. Miller (eds), Handbook of Public Administration. New York: Marcel Dekker, pp. 49-101.

Jann, W. 2001. 'Public Management Reform in Germany: A Revolution without a Theory?', in W. Kickert (ed.), Public Management and Administrative Reform in Western Europe. Cheltenham: Edward Elgar, pp. 81-100.

Jann, W. 2003. 'State, Administration and Governance in Germany: Competing Traditions and Dominant Narratives', Public Administration, 81, 1, 95-118.

Kaelble, H. 2003. 'Die interdisziplinären Debatten über Vergleich und Transfer', in H. Kaelble and J. Schriewer (eds), Vergleich und Transfer. Komparatistik in den Sozial-, Geschichts- und Kulturwissenschaften. Frankfurt/Main: Campus, pp. 469-94.

Kickert, W.J.M. 2001. 'Public Management in the United States and Europe', in W. Kickert (ed.), Public Management and Administrative Reform in Western Europe. Cheltenham: Edward Elgar, pp. 15-40.

Kickert, W.J.M. and R.J. Stillman II (eds). 1999. The Modern State and its Study. New Administrative Sciences in a Changing Europe and United States. Cheltenham: Edward Elgar. 
Lingelbach, G. 2002. 'The Historical Discipline in the United States: Following the German Model?', in E. Fuchs and B. Stutchey (eds), Across Cultural Borders. Historiography in Global Perspective. Lanham, MD: Rowman \& Littlefield, pp. 183-205.

Lüsebrink, H.-J. 2001. 'Kulturtransfer - methodisches Modell und Anwendungsperspektiven', in I. Tömmel (ed.), Europäische Integration als Prozess von Angleichung und Differenzierung. Opladen: Leske und Budrich, pp. 213-26.

Lutz, D.S. 1984. 'The Relative Influence of European Writers on Late Eighteenth-century American Political Thought', American Political Science Review, 78, 1, 189-97.

Lynn, L.E. 2006. 'The New Public Management as an International Phenomenon: A Skeptical View', in E.E. Otenyo and N.S. Lind (eds), Comparative Public Administration: The Essential Readings. Oxford: Elsevier, pp. 573-91.

March, J.G. 1994. A Primer on Decision Making. New York: The Free Press.

March, J.G. and H.A. Simon. 1958. Organizations. New York: John Wiley \& Sons.

Martin, D.W. 1987. 'Déjà Vu: French Antecedents of American Public Administration', Public Administration Review, 47, 4, 297-303.

Marx, F.M. 1967. 'German Administration and the Speyer Academy', Public Administration Review, 27, 5, 403-10.

Marx, F.M. 1969. 'Inventory of Administrative Study In Europe: The Speyer Conference', Public Administration Review, 29, 4, 359-67.

Miewald, R.D. 1984. 'The Origins of Wilson's Thought: The German Tradition and the Organic State', in J. Rabin and J.S. Bowman (eds), Politics and Administration. Woodrow Wilson and American Public Administration. New York: Marcel Dekker, pp. 17-30.

Morin, P. 1979. 'Actualité de Henri Fayol ou l'occasion perdue', in H. Fayol (ed.), Administration Industrielle et Générale. Paris: Dunod, pp. v-xii.

Nelson, D. 1992. 'Scientific Management in Retrospect', in D. Nelson (ed.), A Mental Revolution. Scientific Management since Taylor. Columbus, OH: Ohio State University Press, pp. 5-39.

Osterhammel, J. 2003. 'Transferanalyse und Vergleich im Fernverhältnis', in H. Kaelble and J. Schriewer (eds), Vergleich und Transfer. Komparatistik in den Sozial-, Geschichts-, und Kulturwissenschaften. Frankfurt: Campus, pp. 439-66.

Ostrom, V. 1997. The Meaning of Democracy and the Vulnerability of Democracies: A Response to Tocqueville's Challenge. Ann Arbor, MI: University of Michigan Press.

Overeem, P. 2010. The Politics-Administration Dichotomy: A Reconstruction. Ridderkerk: Ridderprint.

Painter, M. and B.G. Peters. 2010. Tradition and Public Administration. New York: Palgrave Macmillan. 
Pollitt, C. and G. Bouckaert. 2004. Public Management Reform: A Comparative Analysis. Oxford: Oxford University Press.

Raadschelders, J.C.N. 1998. Handbook of Administrative History. London: Transaction.

Raadschelders, J.C.N. 2007. 'Tradition in the Study and Practice of Public Administration: Explorations and the Case of Negotiable Authority', paper presented at the conference 'Governing by Looking Back', Research School of Social Sciences, Australia National University, Canberra, 12-14 December.

Raadschelders, J.C.N. and M. Rutgers. 1999. 'The Waxing and Waning of the State and Its Study: Changes and Challenges in the Study of Public Administration', in W.J.M. Kickert and R.J. Stillman II (eds), The Modern State and its Study. New Administrative Sciences in a Changing Europe and United States. Cheltenham: Edward Elgar, pp. 17-38.

Rohr, J.A. 1993. 'Public Administration and the French State: A Review Essay', Public Administration Review, 53, 5, 437-79.

Rohr, J.A. 1995. Founding Republics in France and America: A Study in Constitutional Governance. Lawrence, KS: University Press of Kansas.

Romano J. 2003. 'James Burnham en France: l'import-export de la "révolution managériale" après 1945', Revue Française de Science Politique, 53, 2, 257-75.

Rosser, C. 2010. 'Woodrow Wilson's Administrative Thought and German Political Theory', Public Administration Review, 70, 4, 547-57.

Rouban, L. 2001. 'The Administrative Modernisation Policy in France', in W.J.M. Kickert (ed.), Public Management and Administrative Reform in Western Europe. Cheltenham: Edward Elgar, pp. 14156.

Rutgers, M.R. 1996. 'The Meaning of Administration. Translating Across Boundaries', Journal of Management Inquiry, 5, 1, 14-20.

Rutgers, M.R. 2000. 'Public Administration and the Separation of Powers in a Cross-Atlantic Perspective', Administrative Theory and Praxis, 22, 2, 287-308.

Rutgers, M.R. 2001. 'Traditional Flavors? The Different Sentiments in European and American Administrative Thought', Administration and Society, 33, 2, 220-44.

Rutgers, M.R. 2003. 'Tracing the Idea of Public Administration: Towards a Renaissance of Public Administration?', in M.R. Rutgers (ed.), Retracing Public Administration. Oxford: Elsevier Science, pp. 1-36.

Sager, F. and C. Rosser. 2009. 'Weber, Wilson, and Hegel: Theories of Modern Bureaucracy', Public Administration Review 69, 6, 1136-47.

Scaff, L. 2006. 'Max Weber's Reception in the United States, 1920-1960', in K.-L. Ay and K. Borchardt (eds), Das Faszinosum Max Weber. Die Geschichte seiner Geltung. Konstanz: UVK, pp. 343-51. 
Scharpf, F.W. 1970. Die politischen Kosten des Rechtsstaats: Eine vergleichende Untersuchung der deutschen und amerikanischen Verwaltungskontrollen. Tübingen: Mohr Siebeck.

Schreurs, P. 2000. Enchanting Rationality. An Analysis of Rationality in the Anglo-American Discourse on Public Organization. Delft: Eburon.

Sherwood, F.P. 1990. 'The Half-Century's Great Books in Public Administration', Public Administration Review, 50, 2, 249-64.

Seibel, W. 1996. 'Administrative Science as Reform: German Public Administration', Public Administration Review, 56, 1, 74-81.

Smith, L. 1942. 'Alexis de Tocqueville and Public Administration', Public Administration Review, 2, 3, 221-39.

Spicer, M. 2004. 'Public Administration, the History of Ideas, and the Reinventing Government Movement', Public Administration Review, 64, 3, 353-62.

Stiefel, E.C. and F. Mecklenburg. 1991. Deutsche Juristen im amerikanischen Exil (1933-1950). Tübingen: J.C.B. Mohr.

Stillman, R.J. II. 1997. 'American vs. European Public Administration: Does Public Administration Make the Modern State, or Does the State Make Public Administration', Public Administration Review, 57, 4, 332-38.

Stillman, R.J. II. 2001. 'Towards a New Agenda for Administrative State Research? A Response to Mark Rutgers's “Traditional Flavors?” Essay', Administration and Society, 33, 4, 480-8.

Stillman, R.J. II. 2003. 'Twenty-First Century United States Governance: Statecraft as Reform Craft and the Peculiar Governing Paradox it Perpetuates', Public Administration, 81, 1, 19-40.

Suppanz, W.2006. "Kultur in einer "Welt in Bewegung": Theoretische Überlegungen zu kultureller Differenz und Kulturtransfer', in W. Schmale and M. Steer (eds), Kulturtransfer in der jüdischen Geschichte. Frankfurt/Main: Campus, pp. 43-56.

Waugh, W.L. 2006. 'The Existentialist Public Administrator', in T.D. Lynch and P.L. Cruise (eds), Handbook of Organization Theory and Management. The Philosophical Approach. London: Taylor \& Francis, pp. 511-28.

Werner, M. and B. Zimmermann. 2006. 'Beyond Comparison: Histoire Croisée and the Challenge of Reflexivity', History and Theory, 45, 1, 30-50.

Wolff, E.A. 1984. 'From an Executive in Government', in H. Fayol (ed.), General and Industrial Management. New York: IEEE Press, pp. v-xiii.

Yang, K., Y. Zhang and M. Holzer. 2008. 'Dealing with Multiple Paradigms in Public Administration Research', in K. Yang and G.J. Miller (eds), Handbook of Research Methods in Public Administration. Boca Raton, FL: CRC Press, pp. 25-44. 